\title{
Seroprevalence and risk factors of Toxoplasma gondii among pregnant women in Adwa district, northern Ethiopia
}

\author{
Mebrahtu Teweldemedhin ${ }^{1 *}$ (D), Amaha Gebremichael', Gebretsadkan Geberkirstos ${ }^{1}$, Haftom Hadush', \\ Tuam Gebrewahid ${ }^{1}$, Solomon Weldegebreal Asgedom², Berihu Gidey ${ }^{3}$, Negasi Asres $^{3}$ and Hailay Gebreyesus ${ }^{3}$
}

\begin{abstract}
Background: Toxoplasma gondii infection is a great health concern to pregnant women and the developing fetus. The aim of this study was to determine the seroprevalence of T. gondii and its associated factors in Adwa district.

Methods: A facility based cross-sectional study was conducted from January to June 2018 in Adwa district. Structured, a pre-tested questionnaire was used to collect the demographic and risk factor related data. Serum sample, collected from each of the study subjects was tested for lgG and IgM anti T.godii specific antibodies using Enzyme-Linked Immunosorbent Assay. A bivariable and multivariable logistic regression model was applied to show association between the dependent and independent variables considering $P<0.05$ and the 95\% confidence interval.

Result: Out of the 360, 128 (35.6\%) pregnant women were found to be positive for antibodies specific to T. gondii. Furthermore, 117 (32.5\%) women were positive only for lgG, and 11 (3.1\%) were positive both for lgM and lgG antibodies. Age, educational level, habit of hand washing after contact with garden soil or domestic animals, presence of domestic cat, history of contact with domestic dog and consumption of raw vegetables were significantly associated with T. gondii.

Conclusion: The seroprevalence of T. gondii among pregnant women in the study area is low compared to the other regions of Ethiopia, and within the range of the seroprevalences in the central and East Africa region. However, efforts should be done to create awareness on the potential risk factors of the parasite in the community.
\end{abstract}

Keywords: Pregnant women, Risk factors, Seroprevalence, Toxoplasma gondii

\section{Background}

Toxoplasmosis is among the major global zoonotic diseases caused by Toxoplasma gondii (T. gondii) that infect almost all warm-blooded animals including humans [1]. Around $30 \%$ of the human population worldwide is chronically infected with $T$. gondii $[2,3]$. The seroprevalence of toxoplasmosis ranged from 10 to $50 \%$ in developed countries and over $80 \%$ in developing tropical countries [4]. Globally, there are 190,100 new cases of congenital toxoplasmosis; 26, 500 (2/1000 live births) being in the Africa region [5]. Studies conducted in some

\footnotetext{
*Correspondence: mebrie1216@gmail.com

${ }^{1}$ Department of Medical Laboratory Sciences, College of Health Sciences,

Aksum University, P.O.BOX: 298, Aksum, Ethiopia

Full list of author information is available at the end of the article
}

parts of Ethiopia had also indicated that there was a high seroprevalence of $T$. gondii (74.73\%) infection with higher odds of infection in pregnant women [6].

T. gondii infection causes severe and life threatening consequences in human beings and particularly it is a great health concern to pregnant women and the developing fetus or newborns [7]. In Ethiopia, about $82 \%$ women of childbearing age haveimmunity to $T$. gondii [8]; the rest may be at risk of developing an acute infection if exposed to the parasite. Maternal infection of $T$. gondii is associated with psychiatric disturbances and poor obstetric outcomes including abortion, still birth and psychomotor retardation. In women, infection was associated with anxiety, depression, schizophrenia spectrum disorders, and suicide attempts [9]. The risk of

(c) The Author(s). 2019 Open Access This article is distributed under the terms of the Creative Commons Attribution 4.0 International License (http://creativecommons.org/licenses/by/4.0/), which permits unrestricted use, distribution, and reproduction in any medium, provided you give appropriate credit to the original author(s) and the source, provide a link to the Creative Commons license, and indicate if changes were made. The Creative Commons Public Domain Dedication waiver (http://creativecommons.org/publicdomain/zero/1.0/) applies to the data made available in this article, unless otherwise stated. 
vertical transmission is lower during the first trimester $(15-20 \%)$ than the third trimester of maternal infection (60-90\%). However, severe fetal disease is associated with the first trimester of maternal infection [10, 11]; an infected fetus may has severe complications such as hearing problems, mental retardation, seizure, Chorioretinitis and hydrocephaly [12-14].

Changing environmental conditions, whether caused by rapid urbanization, global warming or economic globalization, have already influenced the emergence, transmission and distribution of toxoplasmosis [15]. The ecology of $T$. gondii, with its complex life-cycle, is susceptible to environmental changes mainly affecting the survival time and infectivity of oocysts, and the behavior and population density of hosts [16]. Giving antibiotic treatment is not the most effective way to prevent congenital toxoplasmosis and associated complications. Primary prevention is best [17]. Besides, clinical diagnosis of toxoplasmosis is difficult, considering that 90 to $95 \%$ of the infected pregnant women are asymptomatically infected [18] increasing the risk of congenital infection. Therefore, serological screening of $T$. gondii infection is essential to prevent the risk of congenital toxoplasmosis. Upon early screening, the use of drugs such as spiramycine was found to prevent congenital infection by more than $60 \%$ [2].

Ethiopia is one of the countries with low resources including scarcity of safe drinking water supply particularly in the rural communities; with different domestic animals including cats, dogs, goats, sheep and camel and climatic conditions favoring the survival of the parasite. Considering the above hosts and other predisposing factors for T. gondii, research is needed particularly among pregnant women to depict the prevalence of the parasite. Women engage in different home-based activities such as food preparation and caring their children; they are frequently exposed to domestic animals and garden soil. Hence, screening of pregnant women for $T$. gondii infection during their Maternal and Child Health $(\mathrm{MCH})$ service is not only of benefit of the women but also benefit the next generation. However, in most parts of Ethiopia, including the study area, there is no continuous screening program for $T$. gondii because of facility limitations and cases are mostly diagnosed by exclusion. Therefore, the aim of this study was to determine the seroprevalence of $T$. gondii and its associated factors in Adwa district.

\section{Methods}

\section{Study area, period and design}

A facility based cross-sectional study was conducted from January to June 2018 in Adwa district, Central zone of Tigray, Northern Ethiopia, located at a distance of $1006 \mathrm{~km}$ from Addis Ababa (the capital city of Ethiopia).
It is found at an elevation of $1907 \mathrm{~m}$ with a latitude and longitude of $14^{\circ} 10^{\prime} \mathrm{N} 38^{\circ} 54^{\prime} \mathrm{E}$. The district has one general hospital and 3 health centers with a total catchment population of 1,670,001. Adwa is basically an urban dwelling but the hospital and health centers serve for women from urban dwelling as well as from nearby rural dwellings.

\section{Populations}

All pregnant women in Adwa district were the source population; pregnant women who visited public hospitals and health centers in Adwa district comprised the study population.

\section{Sample size determination}

The sample size was calculated based on the single proportion formula because it yielded a maximum sample size.

The sample size was calculated considering, he estimated seroprevalence (p) of $T$. gondii among pregnant women; $68.4 \%$ from the study conducted in Debre Tabor, Ethiopia [19]; considering the $95 \%$ confidence level, $\alpha$ is 0.05 (the level of significance) and the value of $\mathrm{Z}$ at $\alpha / 2$ is 1.96; $d$ is the margin of error (5\%). Therefore, based on these assumptions $n=332$; with $10 \%$ contingency, the final sample size was 365 .

\section{Sampling technique}

Out of the three zones in the catchment of Aksum University, Central zone was selected by lottery method; one district (Adwa) was selected again by lottery method. The total sample size was then proportionally allocated to health facilities in Adwa district (Adwa hospital, Adwa health center, Berhe Gebremedhn health center and Atsedemariam health center) based on their previous flow of pregnant women. Finally, pregnant women who were attending each health institution during the study period were randomly included in the study as per the allocated quota. Pregnant women in the age range of 15-49 years were included whereas pregnant women who were unable to communicate for medical reason were excluded from the study.

\section{Study variables}

Independent variables: Age, occupation, residence, educational level, trimester of pregnancy, history of abortion, history of blood transfusion, history of needle stick injury, presence of domestic cat, consumption of raw meat, consumption of raw milk, consumption of raw vegetables, hand washing after contact with garden soil or domestic animals, source of drinking water, history of contact with sheep/goat, history of contact with camel and history of contact with dog. Dependent variable: Seroprevalence of $T$. gondii. 


\section{Data collection procedures}

\section{Socio-demographic and related data}

Structured, pretested questionnaires, translated in to Tigrigna (local language), were used to collect the demographic and risk factor related data. Recruited health professionals filled the questionnaire by direct interview of the study participants. Patients' medical records were also used to confirm the clinical factors such as history of blood transfusion.

\section{Specimen collection and processing}

After completion of the questionnaire, trained laboratory technologists collected adequate specimen (paired $5-10 \mathrm{ml}$ of venous blood) following aseptic techniques. The whole blood was centrifuged at $3000 \mathrm{rpm}$ for 5 min to get serum sample; tested for IgG and IgM antiT.godii specific antibodies using Enzyme Linked Immunosorbent Assay (ELISA) as per the standard operating procedures. The serums samples were tested using Toxo IgG assay (sensitivity $=99.7 \%$, specificity $=99.6 \%$ ) and Toxo IgM assay (sensitivity = 99.95\%) (ABBOT, ARCHITECT). Reactive serum samples for IgM and or IgG and with high IgG avidity were considered as past infections whereas reactive samples for IgM and IgG with low IgG avidity in the paired serum (second serum specimen taken after 3 weeks of the primary specimen) were considered as recent infections.

\section{Quality assurance}

Strict measures were taken throughout the analytic process. Five percent of the Questionnaire was pre-tested among pregnant women attending at Suhul Hospital (Shire town), and Questionnaire was revised accordingly. Data collectors were trained for 2 days on how to conduct the interview and the sampling process. Completed questionnaires were reviewed immediately to ensure accuracy and legibility. Quality control samples were tested parallel with the research samples and standard operating procedures were followed during the laboratory investigation.

\section{Statistical analysis}

Data were entered into Epiinfo version 3.5.3 and analysis was made using the statistical software SPSS version 21 for Windows. Logistic regression model was applied to show association between the dependent and independent variables. Firstly, bivariable logistic regression model was analyzed to see association between each of the independent and the outcome variable. The independent variables with a $P$ value $<0.05$ in the bivariable logistic regression were together entered to the multivariable logistic regression analysis to adjust potential confounders and analyzed using the enter method. Finally, statistically significant association has been declared considering a $P$ value $<0.05$ and the corresponding 95\% confidence interval.

\section{Results}

Characteristics of the study subjects

This study included a total of 360 pregnant women with a response rate of $98.6 \%$. Majority (65\%) of them were urban dwellers and the mean age $( \pm$ SD) of the study subjects were $26.9( \pm 5.7)$ years (see Table 1$)$.

\section{Seroprevalence of $T$. gondii and its associated factors}

In this study, the serum sample was collected from a total of 360 pregnant women for the serological test, out of this, 128 (35.6\%) were found to be positive for antibodies specific to $T$. gondii. Furthermore, 117 (32.5\%) were found to be positive only for IgG; the rest 11 (3.1\%) were positive both for IgM and IgG. Out of the 11 women with recent infection, 7 were in the first trimester, 3 were in the second trimester and only 1 mother was in the third trimester of pregnancy.

According to the bivariable logistic regression analysis, 12 variables including residence, age, occupation, educational level, trimester of pregnancy, source of drinking water, hand washing, presence of demotic cat, contact with dog, contact with domestic goat/sheep and consumption of raw vegetables were found to be significantly associated with seroprevalence of $T$. gondii (Table 2). However, after the Multivariate analysis, the statistically significant predictors were Age $[\mathrm{AOR}=42.5$, 95\%CI:- 12.7-141.7), $P<0.01$ ], educational level [AOR = 5.8, 95\%CI:1.27-26.7, $P=0.02$ ], habit of hand washing after contact with garden soil or domestic animals [AOR = 7.7, 95\%CI:2.7-21.9), $P<0.01]$, presence of domestic cat $[\mathrm{AOR}=5.2,95 \% \mathrm{CI}: 2.36-11.6, P<0.01]$, history of contact with domestic dog $[\mathrm{AOR}=12.9,95 \% \mathrm{CI}: 4.9-34.2$, $P<0.01$ ] and consumption of raw vegetables $[\mathrm{AOR}=6.7$, 95\%CI:2.6-17.2, $P<0.01$ ] (Table 3).

\section{Discussion}

Little was known about the seroprevalence of $T$. gondii in Tigray region and this is the first report of $T$. gondii infection in Adwa, Ethiopia. The seroprevalence of $T$. gondii among pregnant women in the study area was found to be $35.6 \%$. This finding is lower than the findings from Arbaminch, Ethiopia 79.3\% [20], Bench Maji, Ethiopia 85.3\% [21], Brazil 68.37\% [22], Ghana 51.2\% [23] but higher than the findings in Tanzania 30.9\% [24], Sri Lanka 30.27\% [25], China 18.1\% [26] and Mexico $11 \%$ [27]. The current finding is also lower than the seroprevalence of $T$. gondii in the lower altitude and higher humidly cities of Kenya, Kisumu (52\%) and Mombasa (57\%) [28]. Among the seropositive women, the majority of them were found to have a chronic or 
Table 1 Socio-demographic characteristics, behavioral and clinical factors of the study subjects $(n=360)$

\begin{tabular}{|c|c|c|c|}
\hline Socio-demographic Variables & Categories & Frequency(n) & Percent (\%) \\
\hline \multirow[t]{2}{*}{ Residence } & Rural & 126 & 35.0 \\
\hline & Urban & 234 & 65.0 \\
\hline \multirow[t]{3}{*}{ Age } & $15-24$ & 117 & 32.5 \\
\hline & $25-34$ & 178 & 49.4 \\
\hline & $>/=35$ & 65 & 18.1 \\
\hline \multirow[t]{6}{*}{ Occupational } & Student & 45 & 12.5 \\
\hline & House Wife & 143 & 39.7 \\
\hline & Farmer & 42 & 11.7 \\
\hline & Governmental employee & 65 & 18.1 \\
\hline & Non-governmental employee & 26 & 7.2 \\
\hline & Self employed & 39 & 10.8 \\
\hline \multirow[t]{4}{*}{ Educational status } & Unable to read and write & 47 & 13.1 \\
\hline & $1-8$ & 72 & 20.0 \\
\hline & $9-12$ & 135 & 37.5 \\
\hline & College and above & 106 & 29.4 \\
\hline \multirow[t]{3}{*}{ Trimester of pregnancy } & First trimester & 114 & 31.7 \\
\hline & Second trimester & 130 & 36. \\
\hline & Third trimester & 116 & 32.1 \\
\hline \multirow[t]{3}{*}{ Source of drinking water } & Unprotected well & 23 & 6.4 \\
\hline & protected well & 78 & 21.7 \\
\hline & Tap water & 259 & 71.9 \\
\hline \multirow{3}{*}{$\begin{array}{l}\text { Hand washing after contact with } \\
\text { garden soil or domestic animals }\end{array}$} & Rarely & 85 & 23.6 \\
\hline & Mostly & 120 & 33.3 \\
\hline & Always & 155 & 43.1 \\
\hline \multirow[t]{2}{*}{ Domestic cat } & No & 186 & 13.1 \\
\hline & Yes & 174 & 20.0 \\
\hline \multirow[t]{2}{*}{ History contact with dog } & No & 272 & 75.6 \\
\hline & Yes & 88 & 24.4 \\
\hline \multirow[t]{2}{*}{ History of Contact with goat/sheep } & No & 285 & 79.2 \\
\hline & Yes & 75 & 20.8 \\
\hline \multirow[t]{2}{*}{ History of Contact with Camel } & No & 328 & 91.1 \\
\hline & Yes & 32 & 8.9 \\
\hline \multirow[t]{2}{*}{ Used to consume raw meat } & No & 255 & 70.8 \\
\hline & Yes & 105 & 29.2 \\
\hline \multirow[t]{2}{*}{ Used to consume raw milk } & No & 278 & 77.2 \\
\hline & Yes & 82 & 22.8 \\
\hline \multirow[t]{2}{*}{ Used to consume raw vegetables } & No & 128 & 35.6 \\
\hline & Yes & 232 & 64.4 \\
\hline \multirow[t]{2}{*}{ History of abortion } & No & 257 & 71.4 \\
\hline & Yes & 103 & 28.6 \\
\hline \multirow[t]{2}{*}{ History of needle stick injury } & No & 313 & 86.9 \\
\hline & Yes & 47 & 13.1 \\
\hline \multirow[t]{2}{*}{ History of blood transfusion } & No & 303 & 84.2 \\
\hline & Yes & 57 & 15.8 \\
\hline
\end{tabular}


Table 2 Bivariate logistic regression analysis of factors associated with sero-prevalence of $T$. gondii among pregnant women $(n=360)$

\begin{tabular}{llll}
\hline Variable & Sero-status COR $95 \% \mathrm{Cl}$ & P-value \\
& Positive, $\mathrm{n}$ & & \\
& $(\%)$ & & \\
& &
\end{tabular}

Residence

$\begin{array}{ccccc}\text { Rural } & 69(54.8) & 3.59 & \begin{array}{l}(2.270- \\ 5.679)\end{array} & <0.01 \\ \text { Urban } & 59(25.2) & 1 & & \\ \text { Age } & & & & \\ 15-24 & 13(11.1) & 1 & 1 & \\ 25-34 & 65(36.5) & 4.6 & (2.8-8.8) & <0.01 \\ >/=35 & 50(76.9) & 26.6 & (11.8-60.3) & <0.01\end{array}$

Occupation

\begin{tabular}{|c|c|c|c|c|}
\hline Student & $9(20)$ & 0.49 & $(0.2-1.2)$ & 0.116 \\
\hline House wife & $73(51)$ & 2.0 & $(1.1-3.7)$ & 0.022 \\
\hline Farmer & $11(26.2)$ & 0.7 & $(0.3-1.6)$ & 0.4 \\
\hline Governmental employee & $22(33.8)$ & 1 & 1 & \\
\hline $\begin{array}{l}\text { Non-governmental } \\
\text { employee }\end{array}$ & $4(15.4)$ & 0.35 & $(0.1-1.16)$ & 0.086 \\
\hline Self employed & $9(23.1)$ & 0.58 & $(0.23-1.4)$ & 0.24 \\
\hline \multicolumn{5}{|l|}{ Educational level } \\
\hline Unable to read and write & $21(44.7)$ & 2.25 & $(1.09-4.6)$ & 0.03 \\
\hline $1-8$ & $39(54.2)$ & 3.3 & $(1.7-6.2)$ & $<0.01$ \\
\hline $9-12$ & $40(29.6)$ & 1.17 & $(0.6-2.1)$ & 0.5 \\
\hline College and above & $28(26.4)$ & 1 & & \\
\hline \multicolumn{5}{|l|}{ Trimester of pregnancy } \\
\hline First trimester & $41(36.0)$ & 0.88 & $(0.52-1 . .5)$ & 0.65 \\
\hline Second trimester & $42(32.3)$ & 0.75 & $(0.4-1.3)$ & 0.28 \\
\hline Third trimester & $45(38.8)$ & 1 & & \\
\hline \multicolumn{5}{|l|}{ Source of drinking water } \\
\hline Unprotected well & $14(60.9)$ & 3.5 & $(1.5-8.5)$ & $<0.01$ \\
\hline Protected well & $35(44.9)$ & 1.8 & $(1.1-3.1)$ & 0.02 \\
\hline Tap water & 79 (30.5) & 1 & & \\
\hline
\end{tabular}

Hand washing after contact with garden soil and/or domestic animals

$\begin{array}{lllll}\text { Rarely } & 48(56.5) & 2.8 & (1.6-5.0) & <0.01 \\ \text { Mostly } & 32(26.7) & 0.811 & (0.5-1.4) & 0.436 \\ \text { Always } & 48(31) & 1 & & \end{array}$

Presence of domestic cat

$\begin{array}{lllll}\text { No } & 42(22.6) & 1 & & \\ \text { Yes } & 86(49.4) & 3.35 & (2.13-5.3) & <0.01 \\ \text { History contact with dog } & & & & \\ \text { No } & 80(29.4) & 1 & & \\ \text { Yes } & 48(54.5) & 2.8 & (1.76-4.7) & <0.01\end{array}$

History of contact with goat/sheep

$\begin{array}{lllll}\text { No } & 91(31.9 \%) & 1 & & \\ \text { Yes } & 37(49.3) & 2.076 & (1.24-3.5) & 0.01\end{array}$

Table 2 Bivariate logistic regression analysis of factors associated with sero-prevalence of $T$. gondii among pregnant women $(n=360)$ (Continued)

\begin{tabular}{|c|c|c|c|c|}
\hline \multirow[t]{2}{*}{ Variable } & Sero-status & COR & $95 \% \mathrm{Cl}$ & $P$-value \\
\hline & \multicolumn{4}{|l|}{$\begin{array}{l}\text { Positive, n } \\
(\%)\end{array}$} \\
\hline \multicolumn{5}{|c|}{ History of Contact with Camel } \\
\hline No & $113(34.5)$ & 1 & & \\
\hline Yes & $15(46.9)$ & 1.67 & $(0.8-3.5)$ & 0.16 \\
\hline \multicolumn{5}{|c|}{ Used to consume raw meat } \\
\hline No & $86(33.7)$ & 1 & & \\
\hline Yes & $42(40.0)$ & 1.31 & $(0.8-2.09)$ & 0.25 \\
\hline \multicolumn{5}{|c|}{ Used to consume raw vegetables } \\
\hline No & $26(20.3)$ & 1 & & \\
\hline Yes & $102(44.0)$ & 3.078 & $(1.8-5.08)$ & $<0.01$ \\
\hline \multicolumn{5}{|c|}{ Used to consume raw milk } \\
\hline No & $98(35.3)$ & 1 & & \\
\hline Yes & $30(36.6)$ & 1.06 & $(0.6-1.7)$ & 0.8 \\
\hline \multicolumn{5}{|c|}{ History of abortion } \\
\hline No & $90(35.0)$ & 1 & & \\
\hline Yes & 38 (36.9) & 1.08 & $(0.6-1.7)$ & 0.7 \\
\hline \multicolumn{5}{|c|}{ History of needlestick injury } \\
\hline No & $110(35.1)$ & 1 & & \\
\hline Yes & $18(38.3)$ & 1.14 & $(0.6-2.15)$ & 0.67 \\
\hline \multicolumn{5}{|c|}{ History of blood transfusion } \\
\hline No & $111(36.6)$ & 1 & & \\
\hline Yes & $17(29.8)$ & 0.7 & $(0.4-1.35)$ & 0.3 \\
\hline
\end{tabular}

Note: $\mathrm{Cl}$ confidence interval, COR Crude Odds Ratio; 1: referent

past infection. However, eleven women $(11 / 128,8.5 \%)$ or $3.1 \%$ of the 360 women was found to have a recent infection which is almost comparable to the studies conducted in other regions of Ethiopia [20, 21]. Considering the asymptomatic nature of the disease and the possibility of congenital spread, the serologic finding of this study should not be ignored. This is because the healthcare facilities in the study area lack specific tests for $T$. gondii; diagnosis is made by exclusion which may result in misdiagnosis or delayed diagnosis.

In this study, different risk factors have been assessed for the seroprevalence of $T$. gondii. Accordingly, the risk of contracting $T$. gondii had increased with age of the pregnant women; increased odds of having $T$. gondii infection was observed in the age group of greater than 24 years as compared to pregnant women in the age group of 15-24 years. This finding is consistent with the studies conducted in Tanzania [24] and Mali [29]. The seroprevalence of $T$. gondii associated with increasing maternal age might be attributed to the increased risk of contracting infection (7\%) for 1 year increase of maternal age [7]. Pregnant women who were unable to read 
Table 3 Multivariate logistic regression analysis of factors associated with seroprevalence of $T$. gondii among pregnant women $(n=$ 360)

\begin{tabular}{|c|c|c|c|}
\hline Variable & Sero-status, n (\%) & $\begin{array}{l}\text { COR }(95 \% \mathrm{Cl}) \\
P \text {-value }\end{array}$ & $\begin{array}{l}\text { AOR }(95 \% \mathrm{Cl}) \text {, } \\
P \text {-value }\end{array}$ \\
\hline \multicolumn{4}{|l|}{ Positive, n(\%) } \\
\hline \multicolumn{4}{|l|}{ Residence } \\
\hline Rural & $69(54.8)$ & $3.6(2.3-5.7),<0.01$ & $1.6(0.49-5.6), 0.41$ \\
\hline Urban & $59(25.2)$ & 1 & 1 \\
\hline \multicolumn{4}{|l|}{ Age } \\
\hline $15-24$ & $13(11.1)$ & 1 & \\
\hline $25-34$ & $65(36.5)$ & $4.6(2.4-8.8),<0.01$ & $15.6(5.9-40.9),<\mathbf{0 . 0 1}$ \\
\hline$>/=35$ & $50(76.9)$ & $26.6(11.8-60.3)_{,}<0.01$ & $42.5(12.7-141.7),<0.01$ \\
\hline \multicolumn{4}{|l|}{ Occupation } \\
\hline Student & $9(20)$ & $0.49(0.2-1.2), 0.1$ & $0.4(0.08-2.01), 0.27$ \\
\hline House Wife & $73(51)$ & $2(1.1-3.7), 0.02$ & $0.62(0.18-2.1), 0.45$ \\
\hline Farmer & $11(26.2)$ & $0.7(0.3-1.6)$ & $0.64(0.17-2.3), 0.51$ \\
\hline Governmental employee & $22(33.8)$ & 1 & 1 \\
\hline Non-governmental employee & $4(15.4)$ & $0.35(0.1-1.16), 0.08$ & $0.21(0.03-1.3), 0.09$ \\
\hline Self employed & $9(23.1)$ & $0.58(0.23-1.4), 0.24$ & $0.5(0.12-2.47), 0.4$ \\
\hline \multicolumn{4}{|l|}{ Educational level } \\
\hline Unable to read and write & $21(44.7)$ & $2.25(1.09-4.6), 0.03$ & $5.8(1.27-26.7), \mathbf{0 . 0 2}$ \\
\hline $1-8$ & $39(54.2)$ & $3.3(1.7-6.2),<0.01$ & $2.9(0.7-11.7), 0.13$ \\
\hline $9-12$ & $40(29.6)$ & $1.17(0.6-2.1), 0.5$ & $3.2(1.09-9.1), \mathbf{0 . 0 3}$ \\
\hline College and above & $28(26.4)$ & 1 & 1 \\
\hline \multicolumn{4}{|l|}{ Source of drinking water } \\
\hline Unprotected well & $14(60.9)$ & $3.5(1.5-8.5),<0.01$ & $1.3(0.24-7.18), 0.7$ \\
\hline Protected well & $35(44.9)$ & $1.8(1.1-3.1), 0.02$ & $0.6(0.2-1.80), 0.4$ \\
\hline Tap water & $79(30.5)$ & 1 & 1 \\
\hline \multicolumn{4}{|c|}{ Hand washing after contact with garden soil or domestic animals } \\
\hline Rarely & $48(56.5)$ & $2.8(1.6-5.0)$ & $7.7(2.7-21.9)_{,}<\mathbf{0 . 0 1}$ \\
\hline Mostly & $32(26.7)$ & $0.8(0.5-1.4), 0.4$ & $0.46(02-1.06), 0.07$ \\
\hline Always & $48(31)$ & 1 & 1 \\
\hline \multicolumn{4}{|l|}{ Presence of domestic cat } \\
\hline No & $42(22.6)$ & 1 & 1 \\
\hline Yes & $86(49.4)$ & $3.35(2.13-5.3),<0.01$ & $5.2(2.36-11.6),<\mathbf{0 . 0 1}$ \\
\hline \multicolumn{4}{|l|}{ History contact with dog } \\
\hline No & $80(29.4)$ & 1 & 1 \\
\hline Yes & $48(54.5)$ & $2.8(1.7-4.7),<0.01$ & $12.9(4.9-34.2),<\mathbf{0 . 0 1}$ \\
\hline \multicolumn{4}{|l|}{ History of contact with goat/sheep } \\
\hline No & $91(31.9)$ & 1 & 1 \\
\hline Yes & $37(49.3)$ & $2.07(1.2-3.5), 0.01$ & $1.5(0.5-4.7), 0.4$ \\
\hline \multicolumn{4}{|l|}{ History of Contact with Camel } \\
\hline No & $113(34.5)$ & 1 & 1 \\
\hline Yes & $15(46.9)$ & $1.67(0.8-3.5), 0.16$ & $0.5(0.18-1.6), 0.29$ \\
\hline \multicolumn{4}{|l|}{ Used to consume raw meat } \\
\hline No & $86(33.7)$ & 1 & 1 \\
\hline Yes & $42(40.0)$ & $1.3(0.8-2.09), 0.25$ & $1.7(0.8-3.5), 0.17$ \\
\hline
\end{tabular}


Table 3 Multivariate logistic regression analysis of factors associated with seroprevalence of T. gondii among pregnant women $(n=$ 360) (Continued)

\begin{tabular}{|c|c|c|c|}
\hline Variable & Sero-status, n (\%) & $\begin{array}{l}\text { COR }(95 \% \mathrm{Cl}), \\
P \text {-value }\end{array}$ & $\begin{array}{l}\text { AOR }(95 \% \mathrm{Cl}) \text {, } \\
P \text {-value }\end{array}$ \\
\hline \multicolumn{4}{|c|}{ Used to consume raw vegetables } \\
\hline No & $26(20.3)$ & 1 & 1 \\
\hline Yes & $102(44)$ & $3.07(1.8-5.08),<0.01$ & $6.7(2.6-17.2),<\mathbf{0 . 0 1}$ \\
\hline \multicolumn{4}{|c|}{ Used to consume raw milk } \\
\hline No & $98(35.3)$ & 1 & 1 \\
\hline Yes & $30(36.6)$ & $1.06(0.6-1.7), 0.8$ & $2.05(0.86-4.8), 0.1$ \\
\hline \multicolumn{4}{|c|}{ History of abortion } \\
\hline No & $90(35.0)$ & 1 & 1 \\
\hline Yes & $38(36.9)$ & $1.08(0.6-1.7), 0.7$ & $0.8(0.36-1.7), 0.6$ \\
\hline \multicolumn{4}{|c|}{ History of needlestick injury } \\
\hline No & $110(35.1)$ & 1 & 1 \\
\hline Yes & $18(38.3)$ & $1.14(0.6-2.15), 0.67$ & $2.8(0.9-8.9), 0.07$ \\
\hline \multicolumn{4}{|c|}{ History of blood transfusion } \\
\hline No & $111(36.6)$ & 1 & 1 \\
\hline Yes & $17(29.8)$ & $0.7(0.4-1.35), 0.3$ & $0.29(0.07-1.07), 0.6$ \\
\hline
\end{tabular}

and write were 5.8 times more likely to be infected as compared to those who had at least college education; however, this might be due to lack of awareness of the potential risks, proximity to domestic animals, and gardening. The odds of having T. gondii were 7.7 times higher among pregnant women who rarely wash their hands after contact with garden soil and or domestic animals as compared to those women who always wash their hands. Those pregnant women with a history of contact with a domestic dog and those who used to consume raw vegetables had 12.9 and 6.7 times increased odds of $T$. gondii infection respectively as compared to their counterparts. In addition, pregnant women who own domestic cat had 5.2 times higher odds of being seropositive for $T$. gondii. Supporting these findings, contact with garden soil, owing to a domestic dog or cat, and consumption of raw vegetables was significantly associated with $T$. gondii infection in other studies conducted in Ethiopia [20, 21, 30], China [31], and Brazil [32].

Cats and dogs are thought to be the important amplifiers of infection of $T$. gondii [33, 34]. In the Ethiopian context, it is common to see domestic cats live and sleep together with human beings. Cats can directly contaminate humans, other animals, and their surrounding through their feces [7]. Likewise, after contact with cat's feces, dogs can contribute to the transmission of the organism through mechanical contamination of garden soil, vegetables, and human beings. Hence, human beings can possibly acquire the infection or ingest the oocyst of the parasite through their contaminated hands after direct contact with cats or dogs, garden soil, and surfaces or consumption of contaminated vegetables. Oocysts of $T$. gondii are tough free-living stages of the parasite, and therefore are a major contributor to infections associated with the aforementioned risk factors because they [35]. On the other hand, dogs may acquire the infection from other warm-blooded animals through carnivore contamination, and in turn infect human beings [36].

\section{Conclusion}

In conclusion, the seroprevalence of $T$. gondii among pregnant women in the study area is low compared to the other regions of Ethiopia, and within the range of the seroprevalences in the central and East Africa region. The main risk factors were increasing maternal age, educational level, lack of hand washing after contact with garden soil or domestic animals, the presence of a domestic cat, history of contact with domestic dog and consumption of raw vegetables. Efforts should be done to create awareness on the potential risk factors of the parasite in the community.

\section{Abbreviations}

ELISA: Enzyme Linked Immunosorbent Assay; IgG: Immunoglobulin G; IgM: Immunoglobulin M; MCH: Maternal and Child Health

\section{Acknowledgements}

We would like to acknowledge the study participants for their willingness to participate.

\section{Funding}

This work was funded by Aksum University. The funder financed the process of data collection including the materials needed for data collection. 


\section{Availability of data and materials}

The data set used and/or analyzed during the current study is available from the corresponding author on reasonable request.

\section{Authors' contributions}

MT, GG, NA and HG: conceived and designed the project, did the statistical analysis and wrote the manuscript; AG, HH, SW, TG and BG: participated in the data collection and statistical analysis. All authors read and approved the final version of the manuscript.

\section{Ethics approval and consent to participate}

Ethical clearance was obtained from Aksum University College of Health Sciences Research Ethics Review Committee. Official permission was also obtained from Tigray Regional Health Bureau, and the selected Health Institutions. Written informed consent was taken and study subjects were not forced to give consent. For the study subjects who were under the age of 16 , assent was taken from their parents before the actual interview.

\section{Consent for publication}

\section{Not applicable.}

\section{Competing interests}

The authors declare that they have no competing interests.

\section{Publisher's Note}

Springer Nature remains neutral with regard to jurisdictional claims in published maps and institutional affiliations.

\section{Author details}

'Department of Medical Laboratory Sciences, College of Health Sciences, Aksum University, P.O.BOX: 298, Aksum, Ethiopia. ${ }^{2}$ School of Pharmacy, College of Health Sciences, Mekelle University, Mekelle, Tigray, Ethiopia. ${ }^{3}$ Department of Public Health, College of Health Sciences, Aksum University, Aksum, Ethiopia

Received: 10 October 2018 Accepted: 25 March 2019

Published online: 16 April 2019

\section{References}

1. Liu Q, Singla LD. H. Z. Vaccines against toxoplasma gondii: status, challenges and future directions. Hum Vacc Immunother. 2012;8:1305-8.

2. Montoya JG, Remington JS. Management of Toxoplasma gondii infection during pregnancy. Clin Infect Dis. 2008;47:554-66.

3. Moncada PA. JG M. Toxoplasmosis in the fetus and newborn: an update on prevalence, diagnosis and treatment. Expert Rev Anti-Infect Ther. 2012;10: 815-28

4. Kaplan JE, Benson C, Holmes KH, Brooks JT, Pau A, Masur H, et al. Guidelines for prevention and treatment of opportunistic infections in HIV-infected adults and adolescents: recommendations from CDC, the National Institutes of Health, and the HIV medicine Association of the Infectious Diseases Society of America. MMWR Recomm Rep. 2009;58(RR-4):1-207.

5. Torgerson PR, Mastroiacovo P. The global burden of congenital toxoplasmosis: a systematic review. Bull World Health Organ. 2013;91(7): 501-8.

6. Gebremedhin EZ, Tadesse G. A meta-analysis of the prevalence of toxoplasma gondii in animals and humans in Ethiopia. Parasit Vectors. 2015; 8:291

7. Alsammani MA. Sero-epidemiology and risk factors for toxoplasma gondii among pregnant women in Arab and African countries. J Parasit Dis. 2016; 40(3):569-79.

8. Gebremedhin EZ, Abebe AH, Tessema TS, Tullu KD, Medhin G, Vitale M, et al. Seroepidemiology of toxoplasma gondii infection in women of childbearing age in Central Ethiopia. BMC Infect Dis. 2013;13:101.

9. Fallahi S, Rostami A, Shiadeh MN, Behniafar H, Paktinat S. An updated literature review on maternal-fetal and reproductive disorders of toxoplasma gondii infection. J Gynecol Obstet Hum Reprod. 2018;47(3):13340. https://doi.org/10.1016/j.jogoh.2017.12.003

10. Holliman RE. Congenital toxoplasmosis: prevention, screening and treatment. J Hosp Infect. 1995;30(Suppl):179-90.

11. Remington JS, Toxoplasmosis JOK. Infectious diseases of the fetus and newborn. 5th ed. Philadelphia: WB Saunders; 2001. p. 205-346.
12. Zhou P, Chen Z, Hai-Long L, Zheng H, He S, Lin R-Q, et al. Toxoplasma gondii infection in humans in China. Parasit Vectors. 2011:4:165.

13. Gilbert RE, Peckham CS. Congenital toxoplasmosis in the United Kingdom to screen or not to screen? J Med Screen. 2002:9:135-41.

14. Andrade GM, Resende LM, Goulart EM, Siqueira AL, Vitor RW, JN J. Hearing loss in congenital toxoplasmosis detected by newborn screening. Braz Otorhinolaryngol. 2008;74:21-8.

15. Patz JA, Graczyk TK, Geller N, Vittor AY. Effects of environmental change on emerging parasitic diseases. Int J Parasitol. 2000;30:1395-405.

16. Meerburg BG, A K. Changing climate-changing pathogens: toxoplasma gondii in North-Western Europe. Parasitol Res. 2009;105:17-24.

17. Thiébau R, Leproust S, Chêne G, Gilbert R. Effectiveness of prenatal treatment for congenital toxoplasmosis: a meta-analysis of individual patients' data. Lancet. 2007; 369(9556):115-122.

18. Sensini A. Toxoplasma gondii infection in pregnancy: opportunities and pitfalls of serological diagnosis. Clin Microbiol Infect. 2006:12:504-12.

19. Agmas B, Tesfaye R, Koye DN. Seroprevalence of toxoplasma gondii infection and associated risk factors among pregnant women in Debre Tabor, Northwest Ethiopia. BMC Res Notes. 2015;8(1):107.

20. Yohanes T, Zerdo Z, Chufamo N, Ashenafi Abossie A. Seroprevalence and associated factors of toxoplasma gondii infection among pregnant women attending in antenatal Clinic of Arba Minch Hospital, South Ethiopia: cross sectional study. Transl Biomed. 2017;8(1):105. https://doi.org/10.2167/21720479.1000105

21. Abamecha F, Awel H. Seroprevalence and risk factors of toxoplasma gondii infection in pregnant women following antenatal care at Mizan Aman general hospital, bench Maji zone (BMZ), Ethiopia. BMC Infect Dis. 2016;16: 460. https://doi.org/10.1186/s12879-016-1806-6.

22. da Silva MG, Vinaud MC, de Castro AM. Prevalence of toxoplasmosis in pregnant women and vertical transmission of toxoplasma gondii in patients from basic units of health from Gurupi, Tocantins, Brazil, from 2012 to 2014. PLoS One. 2015;10(11):e0141700.

23. Ayi I, Sowah AO, Blay EA, Suzuki T, Ohta N, Ayeh-Kumi PF. Toxoplasma gondii infections among pregnant women, children and HIV-seropositive persons in Accra, Ghana. Trop Med Health. 2016:44(1):17.

24. Mwambe B, Mshana SE, Kidenya BR, Massinde AN, Mazigo HD, Michael D, Majinge C, Groß U. Sero-prevalence and factors associated with toxoplasma gondii infection among pregnant women attending antenatal care in Mwanza, Tanzania. Parasit Vectors. 2013;6(1):222.

25. Iddawela D, Vithana SM, Ratnayake C. Seroprevalence of toxoplasmosis and risk factors of toxoplasma gondii infection among pregnant women in Sri Lanka: a cross sectional study. BMC Public Health. 2017; 17(1):930.

26. Cong W, Dong XY, Meng QF, Zhou N, Wang XY, Huang SY, Zhu XQ, Qian AD. Toxoplasma gondii infection in pregnant women: a seroprevalence and case-control study in Eastern China. Biomed Res Int. 2015:2015.

27. Alvarado-Esquivel C. del Carmen Terrones-Saldívar M, Hernández-Tinoco J, Muñoz-Terrones MD, Gallegos-González RO, et al. Seroepidemiology of toxoplasma gondii in pregnant women in Aguascalientes City, Mexico: a cross-sectional study. BMJ Open. 2016;6(7):e012409.

28. Nisbet Al, Omuse G, Revathi G, Adam RD. Seroprevalence data at a private teaching hospital in Kenya: An examination of Toxoplasma gondii, cytomegalovirus, rubella, hepatitis A, and Entamoeba histolytica. PloS one. 2018;13(10):e0204867.

29. Ouologuem DT, Djimde AA, Diallo N, Doumbo OK, Roos DS. Toxoplasma gondii seroprevalence in Mali. J Parasitol. 2013;99:371-4.

30. Zemene E, Yewhalaw D, Abera S, Belay T, Samuel A, Zeynudin A. Seroprevalence of toxoplasma gondii and associated risk factors among pregnant women in Jimma town, southwestern Ethiopia. BMC Infect Dis. 2012;12:337.

31. Sroka S, Bartelheimer N, Winter A, Heukelbach J, Ariza L, Ribeiro H, et al. Prevalence and risk factors of toxoplasmosis among pregnant women in Fortaleza, northeastern Brazil. Am J Trop Med Hyg. 2010;83:528-33.

32. Liu Q, Wei F, Gao S, Jiang L, Lian H, Yuan B, et al. Toxoplasma gondi infection in pregnant women in China. Trans R Soc Trop Med Hyg. 2009; 103:162-6.

33. Maksimov P, Zerweck J, Dubey JP, Pantchev N, Frey CF, Maksimov A, Reimer U, Schutkowski M, Hosseininejad M, Ziller M, Conraths FJ. Serotyping of toxoplasma gondii in cats (Felis domesticus) reveals predominance of type II infections in Germany. PLoS One. 2013;8(11):e80213. 
34. Wang Z, Ge W, Huang SY, Li J, Zhu XQ, Liu Q. Evaluation of recombinant granule antigens GRA1 and GRA7 for serodiagnosis of Toxoplasma gondii infection in dogs. BMC Vet Res. 2014;10(1):158.

35. VanWormer E, Fritz H, Shapiro K, Mazet JA, Conrad PA. Molecules to modeling: toxoplasma gondii oocysts at the human-animal-environment interface. Comp Immunol Microbiol Infect Dis. 2013;36(3):217-31.

36. Robert-Gangneux F, Dardé ML. Epidemiology of and diagnostic strategies for toxoplasmosis. Clin Microbiol Rev. 2012;25(2):264-96.

Ready to submit your research? Choose BMC and benefit from:

- fast, convenient online submission

- thorough peer review by experienced researchers in your field

- rapid publication on acceptance

- support for research data, including large and complex data types

- gold Open Access which fosters wider collaboration and increased citations

- maximum visibility for your research: over $100 \mathrm{M}$ website views per year

At BMC, research is always in progress.

Learn more biomedcentral.com/submissions 